Medicine Updates

Faculty of medicine

April 2021,volume 5, issue 5 https://muj.journals.ekb.egdean@med.psu.edu.eg vice_dean_postgraduate@med.psu.edu.eg DOI: 10.21608/muj.2021.64017.1045

\title{
" Implementation of Quality Standards for Improvement of Pharmacy in Maysara Health Care Unit"
}

Authors:

Amany Adel Ibrahim: physiotherapist at ElQantara Gharb Hospital.

Omnia Adel Ibrahim: physiotherapist at ElQantara Gharb Hospital .

Hager Ahmed abdelal: pharmacist at Maysara healthcare unit.

Sally Gamil Mofied: pharmacist at Maysara healthcare unit.

Mareve Mikhail Awad Allah: pharmacist at ophthalmology hospital.

Salma ahmed Rashad: nurse at Solidarity Hospital.

Michael Albier Gadalla Awad: pharmacist at Al Hayat

Portfoaud hospital. 


\begin{abstract}
$\underline{\text { Abstract }}$
We can say that the outpatient or the external pharmacy is a perfect medium that provides various medical services.

Pharmacists in this pharmacy play different roles that are not only limited to dispensing medication, but also providing multiple services such as giving the medical advices and instructions to the patients to make sure that they are using the medications in the correct way, as well as ensuring that the patient receives the full care desired by the pharmacy members and following up the condition of the patients and to how much extend they are affected by the treatment.
\end{abstract}

\title{
Kev words
}

Health, Patient, Medications and Errors

\section{Introduction}

In this project we are going to discuss the pivotal role of health care quality, including the methodology it provides in its various dimensions that ensures the provision of safe and distinct health care services with the optimal utilization of resources to ensure its continuity and even the continuous improvement of its processes and outputs to achieve the satisfaction of beneficiaries, workers and society as a whole.

All this through an integrated view of health care in which the patient is the main focus and clinical practice based on evidence is its main tool.

\section{Introduction about the outpatient pharmacy in Mavsara health care unit:-}

Maysara healthcare unit is one of many health care units that belong to the newly health care system which is established on July, 2019 at Port Said, Egypt.

Maysara unit is consisted of many different departments such as: quality control department, infection control department, patient care consultation unit, human resources department and pharmaceutical department which contain the outpatient pharmacy.

Our quality team has chosen the outpatient pharmacy as our project to be studied so we can discuss the problems, defects, obstacles facing it and finding solutions to trying overcoming it in the pharmacy. 
In order for the hospitals, healthcare units or any place to take the accreditation there is a very important point which is how much the patient is satisfied about the medical service provided.

So, an enormous part for patient satisfaction about the medical services provided falls on the outpatient pharmacists in their way in giving the right service expected and supplying the correct dispensing medication from the outpatient pharmacy.

\section{Aim of Work}

The research project is aiming to:

- Shed light on the importance of the outpatient pharmacy.

- Achieve safe, timely, efficient, effective patient healthcare, family satisfaction, and safe staff working in the pharmacy.

- Enhancing patient and public involvement to realize the active and critical role of the pharmacy.

- Help the pharmacists to develop their own measurements to identify problems they are facing in the working environment and find proposals for solutions.

- Improve safety of high alert medication and decrease medication errors in dispensing and administration.

- Decrease the waiting time for patients while they are in the process of dispensing their medication.

- Reducing the risk that can occur to the patient from health care associated infection.

- Make balanced assessment of the outpatient pharmacy performance in order to make it functioning better.

- Upgrading the level of medical service and healthcare by the outpatient pharmacy members.

- Improving the use and application of correct and suitable quality control standards in the pharmacy. 


\section{$\underline{\text { Methodology }}$}

The project team performed this work in the pharmacy of MAYSRA Health Unite in Portsaid by collecting data using Quality tools.

\section{Ouality tools used in the studv:}

\section{1-Brainstorming}

\section{Definition}

Brainstorming is a creative technique made by group of people to seek a solution for a specific problem by collecting a list of ideas which are visible to all team . ${ }^{(1)}$

\section{Purpose}

They produce different ideas and encourage open thinking and team work ${ }^{(2)}$.

\section{2- Fish bone}

\section{Definition}

It is also called a cause and effect diagram or Ishikawa diagram, is a tool to enhance the ability of quality improvement team to map the full range of possible causes of a problem in order to reach the solutions. Typically used for root cause analysis. ${ }^{(3)}$

\section{Purpose}

A tool for problem solving.

Detecting the root cause of a problem. ${ }^{(4)}$

\section{3- Check list}

\section{Definition}

It is a tool used to reduce errors by recovering the potential memory lapse and inattention task. "to do list "is an example. A checklist is a schedule, which lays out tasks to be done according to time of day or other factors. ${ }^{(5)}$

\section{Purpose $^{(6)}$}

1. Motivation: Checklists help to complete tasks effectively

2. Productivity: By using a checklist we can complete many tasks efficiently and in a short time, and with less mistakes ,so we become more productive and achieve more each day. 
3. Organization: Checklists can help not to skip any step in the task ,so task become more organized.

4. Excellence: Checklists allow us to deliver an effective care for the customer.

5. Delegation: By dividing tasks into specific tasks.

\section{4- Risk management}

\section{Definition}

Risk management is the identification, assessment, and prioritization of risks (defined in ISO 31000 as the effect of uncertainty on objectives), then utilizing resources efficiently to control the probability or effect of adverse event. ${ }^{(7)}$

\section{Purpose}

Risks management is an important process because it protects an organization from the hidden and potential risk by providing the organization with a clear understanding to identify and deal with these risks. Once a risk's been identified, it is then easy to overcome it. Also, risk management helps the organization to take right actions and make correct decisions. ${ }^{(8)}$

\section{5-Strategic planning}

\section{Definition}

Strategic planning is the process of setting up and designing a direction of the organization by estimating both where you are and where you're going. The strategic plan gives us a place to list our vision, mission, and values, as well as our long-term goals, this will be reached by achieving action plans . ${ }^{(9)}$

\section{Purpose ${ }^{(10)}$}

1- $\quad$ Creates a sense of direction.

2- $\quad$ Increase operational efficiency.

3- Increase market share and profitability.

4- Increase durability and sustainability.

5- $\quad$ Being proactive instead of reactive. 


\section{6-Action plan:}

\section{Definition}

An Action Plan is an organized plan to reach goals by carrying out defined actions and following methodology . An Action Plan has several steps that must be followed to achieve the strategic plan . ${ }^{(11)}$

\section{Purpose}

An action plan clarify what resources are needed to achieve the (SMART) goal and setting the timeline that required. This help organization to have a more specific vision. ${ }^{(12)}$

\section{$\underline{\text { Result }}$}

First: Results of brain storming for problems of the pharmacy

\begin{tabular}{|l|l|}
\hline Problems & Percentage \\
\hline 1-crowded waiting room. & $85 \%$ \\
\hline 2- increase patient waiting time. & $70 \%$ \\
\hline 3- staff stress, over load and crowded work place. & $60 \%$ \\
\hline 4- Lack of number of staff to number of patients.. & $40 \%$ \\
\hline 5- Medication errors. & $30 \%$ \\
\hline 6- Lack of medications . & $20 \%$ \\
\hline
\end{tabular}






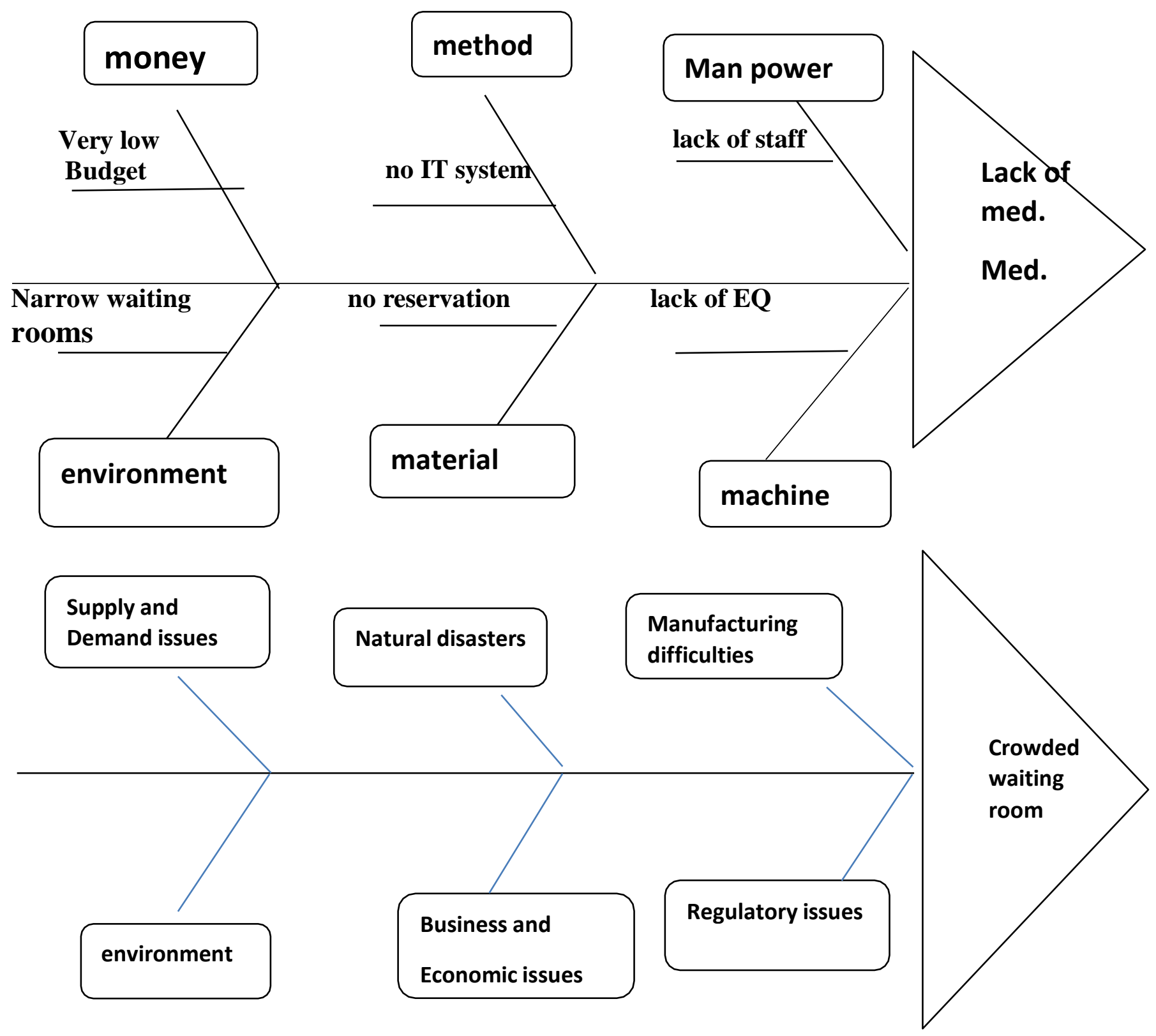


Third: Check lists

Pharmacy inspection checklist

Name of Pharmacy/ -

Date of inspection/-

\begin{tabular}{|l|l|l|l|l|}
\hline Items /Description & Yes & No & N/A & Remarks \\
\hline Pharmacy General Considerations & & $\sqrt{ }$ & & \\
\hline $\begin{array}{l}\text { 1-A display board presenting the } \\
\text { schedule ofworking hours . }\end{array}$ & $\sqrt{ }$ & & & \\
\hline $\begin{array}{l}\text { 3-The pharmacy should be clean with } \\
\text { fresh air . }\end{array}$ & $\sqrt{ }$ & & & \\
\hline $\begin{array}{l}\text { 4- birds and pets must not be in the } \\
\text { pharmacy . }\end{array}$ & $\sqrt{ }$ & & & \\
\hline $\begin{array}{l}\text { 5- "No smoking" sign must be present } \\
\text { in thepharmacy policy . }\end{array}$ & $\sqrt{ }$ & & \\
\hline $\begin{array}{l}\text { 6-Pharmacy Design requirements } \\
\text { Pharmacy closet must be present to display and store medications in } \\
\text { appropriate way .closet should include the following: }\end{array}$ & & \\
\hline $\begin{array}{l}\text { 1- A lockable closet(s) must be supplied } \\
\text { to keepControlled Drugs (CD \& SCD). } \\
\text { The closet(s) must be set away from the } \\
\text { general sales area andshould be } \\
\text { inaccessible to the customer . }\end{array}$ & $\sqrt{ }$ & & & \\
\hline $\begin{array}{l}\text { 2- Expired medications must be labeled } \\
\text { and stored in a specified place away from } \\
\text { the salesarea . }\end{array}$ & $\sqrt{ }$ & & & \\
\hline
\end{tabular}

\begin{tabular}{|l|l|l|l|l|}
\hline $\begin{array}{l}\text { 3-Official report of return or withdrawn } \\
\text { medications must be documented and stored } \\
\text { in specific area away from the sales area }\end{array}$ & $\sqrt{ }$ & & & \\
\hline $\begin{array}{l}\text { 4- Keeping the temperature within the } \\
\text { pharmacy 25degrees Celsius or below by } \\
\text { using an air } \\
\text { conditioning }\end{array}$ & $\sqrt{ }$ & & & \\
\hline $\begin{array}{l}\text { 5-Ensuring that public source of water is } \\
\text { presented with tank and frequent hand } \\
\text { wash. }\end{array}$ & $\sqrt{ }$ & & & \\
\hline $\begin{array}{l}\text { 6- Fire extinguishers and fire protection } \\
\text { equipment }\end{array}$ & $\sqrt{ }$ & & & \\
\hline
\end{tabular}




\begin{tabular}{|l|l|l|l|l|}
\hline should be present within the pharmacy. & & & & \\
\hline $\begin{array}{l}\text { 7- A refrigerator should be } \\
\text { specified forpharmaceutical } \\
\text { products storage only. }\end{array}$ & $\sqrt{ }$ & & & \\
\hline
\end{tabular}


Fourth Strategic planning model to improve quality in the pharmacy

Fifth: Action Plan

\begin{tabular}{|c|c|c|l|l|l|}
\hline Goa & Actio & Person / & & \\
$\mathrm{n}$ & $\begin{array}{c}\text { Group } \\
\text { responsib } \\
\text { le }\end{array}$ & Timeline & Budget & $\begin{array}{c}\mathrm{Kp} \\
\mathrm{i}\end{array}$ \\
\hline
\end{tabular}

\begin{tabular}{|c|c|c|}
\hline $\begin{array}{l}\text { Internal } \\
\text { Environment }\end{array}$ & strength & Weakness \\
\hline & $\begin{array}{l}\text { 1- Good computer system } \\
\text { 2-Qualified pharmacist } \\
\text { team. } \\
\text { 3-large Storage room }\end{array}$ & $\begin{array}{l}\text { 1-Staff to } \\
\text { patient ratio } \\
\text { 1: } 4 . \\
\text { 2-Stress and long shifts. } \\
\text { 3-Lack of some } \\
\text { medications. }\end{array}$ \\
\hline External Environment & Opportunities & Threats \\
\hline & $\begin{array}{l}\text { 1-Availability of many } \\
\text { drugs stock. } \\
\text { 2- Save time. } \\
\text { 3-Data Documentation. }\end{array}$ & $\begin{array}{l}\text { 1- Long shifts and stress } \\
\text { increase chance of } \\
\text { medication errors. } \\
\text { 2-Operational challenges } \\
\text { (time, workload, funding) } \\
\text { 3-Poor customer. } \\
\text { services(late, missing } \\
\text { doses) } \\
\text { 4-Lack of consistency of } \\
\text { pharmacy services. }\end{array}$ \\
\hline
\end{tabular}




\begin{tabular}{|c|c|c|c|c|c|}
\hline $\begin{array}{l}\text { Medicat } \\
\text { ion } \\
\text { Safety }\end{array}$ & $\begin{array}{l}\text { 1- Separate } \\
\text { LASA } \\
\text { medication } \\
\text { on the shelf. } \\
\text { 2-Identify } \\
\text { your } \\
\text { LASA list. } \\
\text { 3- Eliminat } \\
\text { e } \\
\text { handwritte } \\
\text { n and } \\
\text { telephone } \\
\text { prescriptio } \\
\text { ns outside } \\
\text { of } \\
\text { emergencie } \\
\mathrm{s}\end{array}$ & pharmacists & $\begin{array}{l}\text { From } \\
11 / 2020 \\
\text { To } \\
11 / 2021\end{array}$ & No budget & $40 \%$ \\
\hline $\begin{array}{l}\text { Managing } \\
\text { Drug } \\
\text { shortage } \\
\cdot\end{array}$ & $\begin{array}{l}\text { 1-patients } \\
\text { shouldbe } \\
\text { priotrized } \\
\text { based on } \\
\text { severity of } \\
\text { disease . } \\
\text { 2-utilize } \\
\text { risk } \\
\text { manageme } \\
\text { nt for } \\
\text { patient } \\
\text { policy. } \\
\text { 2-identificati } \\
\text { on of current } \\
\text { drug } \\
\text { shortages } \\
\text { and } \\
\text { reporting for } \\
\text { shortsupply } \\
\text { of the drug. } \\
\text { 3-Establish }\end{array}$ & Pharmacists & \begin{tabular}{|l} 
From \\
$11 / 2020$ \\
To \\
$11 / 2021$
\end{tabular} & No budget & $40 \%$ \\
\hline
\end{tabular}




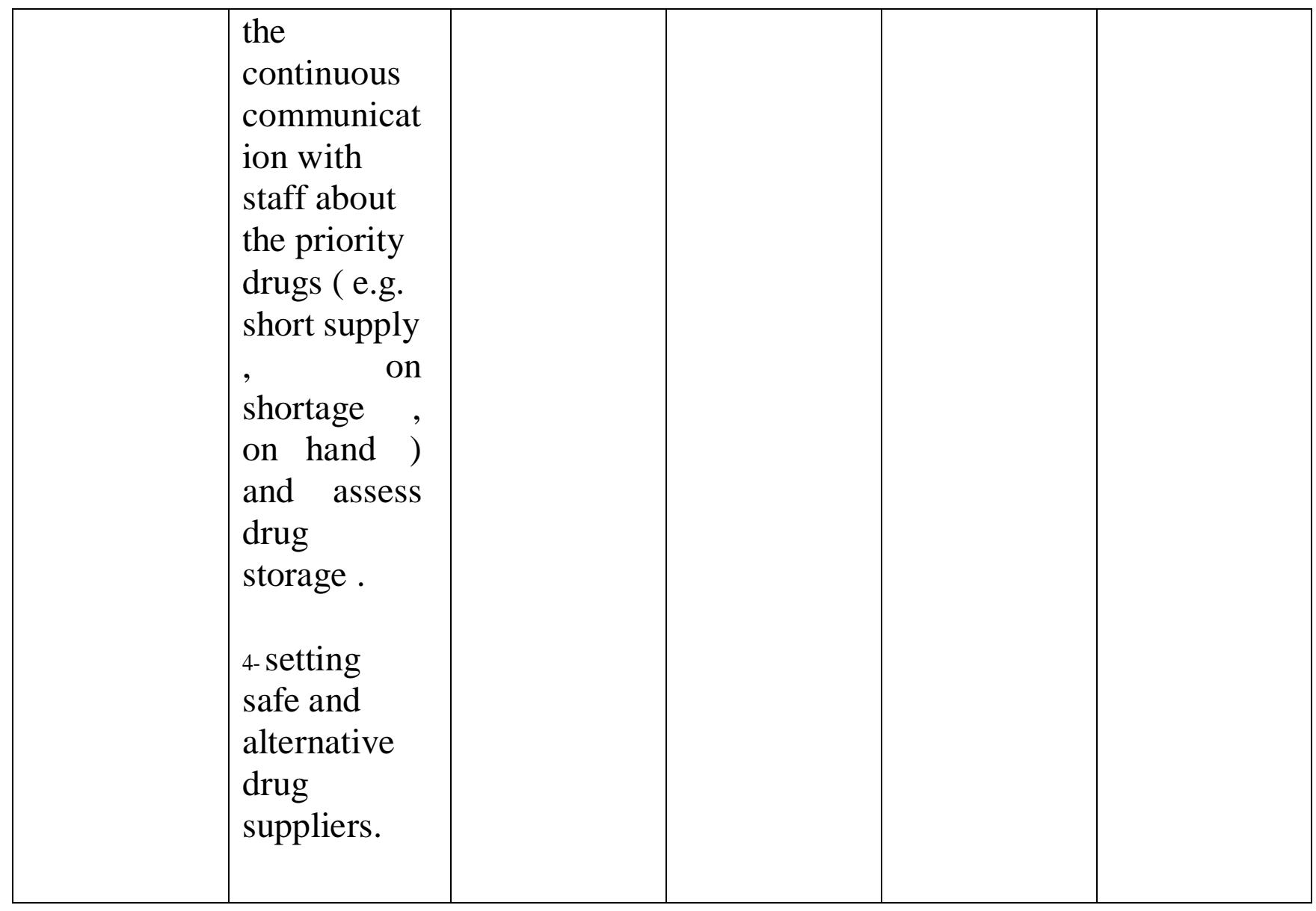


Sixth: Risk management plan

\begin{tabular}{|c|c|c|c|c|c|c|c|}
\hline Risk & Goal & objectives & Activities & $\begin{array}{l}\text { Starting/ } \\
\text { Ending } \\
\text { date }\end{array}$ & Team & KPI & $\begin{array}{l}\text { Budg } \\
\text { et }\end{array}$ \\
\hline $\begin{array}{l}\text { Deliver } \\
\text { ing } \\
\text { files }\end{array}$ & $\begin{array}{l}\text { Safe } \\
\text { time }\end{array}$ & $\begin{array}{l}\text { Prevent } \\
\text { wasting } \\
\text { time }\end{array}$ & $\begin{array}{l}\text { Increase the } \\
\text { working time by } \\
\text { half an hour for } \\
\text { delivering files } \\
\text { in a proper way }\end{array}$ & $\begin{array}{l}\text { From } \\
11 / 202 \\
0 \\
\text { To } 06 / 2021\end{array}$ & $\begin{array}{l}\text { pharma } \\
\mathrm{c} \text { ist }\end{array}$ & $10 \%$ & $\begin{array}{l}\text { No } \\
\text { budg } \\
\text { et }\end{array}$ \\
\hline $\begin{array}{l}\text { Patient } \\
\text { Identifi } \\
\text { cation }\end{array}$ & $\begin{array}{l}\text { Patie } \\
\text { nt } \\
\text { safety }\end{array}$ & $\begin{array}{l}\text { Making } \\
\text { patients } \\
\text { fileswith } \\
\text { quadrant } \\
\text { name - } \\
\text { Electronic } \\
\text { number - }\end{array}$ & $\begin{array}{l}\text { Training to the } \\
\text { medical team by } \\
\text { thequality team } \\
\text { on the new } \\
\text { system. }\end{array}$ & $\begin{array}{l}\text { From } \\
11 / 202 \\
0 \\
\text { To } 06 / 2021\end{array}$ & $\begin{array}{l}\text { pharma } \\
\mathrm{c} \text { ist }\end{array}$ & $30 \%$ & $\begin{array}{l}\text { No } \\
\text { budg } \\
\text { et }\end{array}$ \\
\hline $\begin{array}{l}\text { Equipm } \\
\text { e nt } \\
\text { breakdo } \\
\text { wn }\end{array}$ & $\begin{array}{l}\text { Continu } \\
\text { ity of } \\
\text { service }\end{array}$ & $\begin{array}{l}\text { To } \\
\text { decrease } \\
\text { the } \\
\text { breakdown } \\
\text { of } \\
\text { equipment }\end{array}$ & $\begin{array}{l}\text { Contact with } \\
\text { supply } \\
\text { management to } \\
\text { provide spare parts } \\
\text { forbreak down } \\
\text { machine }\end{array}$ & $\begin{array}{l}\text { From } \\
11 / 202 \\
0 \\
\text { To } \\
06 / 20 \\
2 \\
1 \\
\end{array}$ & $\begin{array}{l}\text { pharma } \\
\mathrm{c} \text { ist }\end{array}$ & $30 \%$ & $\begin{array}{l}\text { No } \\
\text { budg } \\
\text { et }\end{array}$ \\
\hline $\begin{array}{l}\text { Medicat } \\
\text { io n } \\
\text { error of } \\
\text { work }\end{array}$ & $\begin{array}{l}\text { Patie } \\
\text { nt } \\
\text { safety }\end{array}$ & $\begin{array}{l}\text { Prevent } \\
\text { any } \\
\text { medical } \\
\text { mistake in } \\
\text { prescriptio } \\
\mathrm{n} \\
\text { dispensing } \\
\text { and } \\
\text { administrat } \\
\text { ion }\end{array}$ & $\begin{array}{l}\text {-put the polices in } \\
\text { use } \\
\text { - mark look alike } \\
\text { drugs with green } \\
\text { label } \\
\text {, sound alike } \\
\text { drugs with } \\
\text { yellow label, } \\
\text { high alert drugs } \\
\text { withred label and } \\
\text { high } \\
\text { concentration } \\
\text { drugs with blue } \\
\text { label. } \\
\text {-preparing } \\
\text { medications } \\
\text { inspecial } \\
\text { boxes. }\end{array}$ & $\begin{array}{l}\text { From } \\
11 / 202 \\
0 \\
\text { To 06/2021 }\end{array}$ & $\begin{array}{l}\text { pharma } \\
\mathrm{c} \text { ist }\end{array}$ & $30 \%$ & $\begin{array}{l}\text { No } \\
\text { budg } \\
\text { et }\end{array}$ \\
\hline
\end{tabular}




\section{Discussion}

The project team performed this work in the Maysara Pharmacy Health unit collecting data by using quality tools in the period from November 2020 to February 2021.

From the quality tools used, it is noticed that the most problem facing the pharmacy is medication error providing the correct drug to correct patient with correct dose is a complex process . Errors may be occur during prescribing ,dispensing ,preparation ,transcribing, administration ,monitoring ,...etc, most common causes of medication error include the decision of physicion is incorrect , error during writing prescription on paper or system, incorrect dose, drug administration is incorrect due to lack of patient education, dispensing incorrect drug to patient, incorrect monitoring to cases. especially which need laboratory analysis to continue or stop some drugs.

Ordering errors include drug with no valid indication, indication without medication, therapeutic doublication,wrong dose regimen, wrong duration, wrongadministration route ,...etc

Ordering process errors include wrong patient, incomplete patient information, wrong drug name, incomplete prescribing instructions ,...etc

Dispensing errors include wrong patient, wrong label, wrong drug, wrong dosageform, omission ...etc

All these errors can be detected and corrected by double check for patient information and drugs before the administration of the medication to reduce medication error we care about How ? not Who and there is a big difference

To prevent medication errors follow the rights of medication administration : right patient, right drug, right dose . right time, right route, right recording, right assessment, right education, right evaluation and right to refuse medication

Health care organizations shouldn't accept any error in medical care system , they should evaluate errors when they occur and make changes in the drug delivery process to prevent the error to reoccur. 


\section{$\underline{\text { Conclusion }}$}

\section{From the result of the research, project study team concluded that}

- The most common problems in the pharmacy are lack of number of staff, stress and over load work.

- The most defects in patient safety are medication error .

- No good policy for admission and plan for discharge are found.

- Work Load is the most effective factor in health care problems especially lack of number of pharmacists to number of patient.

- Crowding on the pharmacy to maintain medication is a main contributing factor in infection spread.

- Administration support enhancing quality improvement in pharmacy.

- Presence of well qualified occupational pharmacist team is a must to provide quality improvement.

- Preventing unnecessary movement, decreasing medication errors and increasing staff efficiency.

- High safety standards increase a reputation and patient satisfaction levels.

- There are many different right ways through which the health care system can be developed. As for the pharmaceutical field, it can be developed through training for pharmacists and providing them continuously with up to date informations through continuous education programs and scientific lectures. So, they become able to deal literally with patients and everything that concerns them, in addition to dealing with their colleagues at work, including doctors, nurses, technicians and all those who work within the health facility. 


\section{Recommendation}

From the results and conclusion of this research and after studying and using different quality tools ,the following are recommended by this research group:

- Human resource should provide pharmacists to decrease patient complain, decrease stress, over load work and improve service performance.

- Providing qualified sufficient staff leading to decrease medication errors.

- Pharmacists' team should minimize medication errors and making look alike, sound alike, high alert, high concentration list.

- Pharmacist team should mark look alike drugs with green label, sound alike drugs with yellow label, high alert drugs with red label and high concentration drugs with blue label.

- Pharmacist team should make double check on all marked drugs during dispensing to minimize medication errors.

- Pharmacist team should make double check on all marked drugs during dispensing to minimize medication errors.

- They must activate Q. system to organize people on front of the pharmacy without wasting time to organize them.

- Pharmacist should lock the door of the pharmacy to decrease unnecessary movement and decrease stress.

- Pharmacists should give attention to drugs which close to running out and accelerate to bring them to provide stock of drugs and decrease patient complaint.

- They must optimize system activation to decrease medication errors and save time.

- Pharmacists should commit to arrange medication with FEFO(first expire first out )to avoid presence of nearly expired drugs.

- Pharmacists should get rid of stagnant medications to avoid being nearly expired.

- Increase funding for research in patient safety, decrease medication errors and improve level of service .

- Working hours and workload should be reduced. 


\section{Summary}

Providing high _ quality, safe medical care is the primary goal of health systems When the public is alerted to quality failures, such as preventable medication errors resulting in patient harm or death, concerns about the quality of healthcare arise.

As experts in medication delivery, pharmacists plays an integral role in preventing and managing medication errors, however, ensuring safety in health system is a team effort .

Pharmacists need to broaden their responsibilities by taking role in quality and performance improvement projects. Pharmacists are well positioned to assist the healthcare system in improving quality of care, and they are already established as experts in medication management processes.

As pharmacists branch out into the quality arena, they will need to expand their knowledge base with respect to quality. This discussion guide is intended to provide health system pharmacists with the basic tools they need to lead and participate in quality improvement and medication safety initiatives .

The term dispensing error refers to medication errors linked to the pharmacy or to whatever health care professional dispenses the medication. These include errors of commission (e.g. dispensing the wrong drug, wrong dose or an incorrect entry into the computer system) and those of omission (e.g. failure to counsel the patient , screen for interactions or ambiguous language on a label). Errors may be potential - detected and corrected prior to the administration of the medication to the patient. The three most common dispensing errors are: dispensing an incorrect medication, dosage strength or dosage form; miscalculating a dose; and failing to identify drug interactions . 


\section{$\underline{\text { References }}$}

1-https://www.mindtools.com/brainstm.html last visited in 17-2-2019 last visited in 19-1-2021.

2-https://www.interaction-design.org/literature/topics/brainstorming last visited in 19-1-2021

3_https://whatis.techtarget.com/definition/fishbone-diagram last visited in 19-1-2021.

4_ https://whatis.techtarget.com/definition/fishbone-diagram last visited in 19-1-2021

5-https://www.checkli.com last visited in last visited in 19-1-2021

6- Yahoo: First Person: How Checklists Improve Quality, Customer Satisfaction and Profits last visited in 19-1-2021.

7-https://en.wikipedia.org/wiki/Risk management last visited in 19-1-2021.

8- https://corporatefinanceinstitute.com/resources/knowledge/strategy/riskmanagement/ last visited in 19-1-2021.

9- https://sba.thehartford.com/business-management/what-is-strategic-planning last visited in 22-1-2021.

10 - http://www.samanthahoong.org/news/2018/2/17/5-benefits-of-strategicplanning last visited in 22-1-2021

11_ https://www.toolshero.com/personal-development/action-plan/ last visited in 22-1-2021.

12-https://www.toolshero.com/personal-development/action-plan/ last visited in 22-1-2021 . 